\title{
Low expression of BTN3A3 indicates poor prognosis and promotes cell proliferation, migration and invasion in non-small cell lung cancer
}

\author{
Xu Cheng ${ }^{1}$, Tianyu $\mathrm{Ma}^{1}$, Ling $\mathrm{Yi}^{2}$, Chongyu $\mathrm{Su}^{1}$, Xiaojue Wang ${ }^{2}$, Tao Wen ${ }^{1}$, Bing Wang ${ }^{1}$, Yuxuan Wang ${ }^{1}$, \\ Hongtao Zhang ${ }^{2}$, Zhidong Liu ${ }^{1}$
}

${ }^{1}$ No. 2 Department of Thoracic Surgery, Beijing Tuberculosis and Thoracic Tumor Research Institute/Beijing Chest Hospital, Capital Medical University, Beijing, China; ${ }^{2}$ Department of Central Laboratory, Beijing Tuberculosis and Thoracic Tumor Research Institute/Beijing Chest Hospital, Capital Medical University, Beijing, China

Contributions: (I) Conception and design: Z Liu, H Zhang, X Cheng; (II) Administrative support: None; (III) Provision of study materials or patients: T Ma, C Su; (IV) Collection and assembly of data: X Cheng, T Ma, L Yi; (V) Data analysis and interpretation: X Wang, T Wen; (VI) Manuscript writing: All authors; (VII) Final approval of manuscript: All authors.

Correspondence to: Zhidong Liu. No. 2 Department of Thoracic Surgery, Beijing Tuberculosis and Thoracic Tumor Research Institute/Beijing Chest Hospital, Capital Medical University, No. 9 Beiguan Street, Tongzhou District, Beijing 101149, China; Email: liuzhidong_xk@126.com; Hongtao Zhang. Department of Central Laboratory, Beijing Tuberculosis and Thoracic Tumor Research Institute/Beijing Chest Hospital, Capital Medical University, No. 9 Beiguan Street, Tongzhou District, Beijing 101149, China. Email: zhtbeijing@163.com.

Background: The butyrophilin (BTN) family has many members with diverse functions related to immunomodulation, initiation and progression of tumors. BTN3A3 belongs to the BTN family, and exploring its expression and correlation with the prognosis of non-small cell lung cancer (NSCLC) patients has great clinical significance.

Methods: Clinical specimens were used to detect BTN3A3 expression. Small interfering RNA (siRNA) was used to knock down BTN3A3 and analyze the proliferative, migratory and invading ability of the transfected NSCLC cells. Multiplex immunofluorescence staining was used to detect the expression of BTN3A3 protein in the tumor microenvironment (TME). We analyzed the relationship between the expression of BTN3A3 and the clinicopathological features and prognosis of NSCLC patients.

Results: The expression of BTN3A3 in NSCLC tissues was significantly lower than in adjacent tissues, and patients with low expression of BTN3A3 had late clinical stages and lower degree of tumor differentiation. Knocking down BTN3A3 promoted the proliferation, migration and invasion of NSCLC. In the TME, the density of BTN3A3 + tumor cells positively correlated with the density of CD8 $+\mathrm{T}$ cells, and the patients with low expression of BTN3A3 had poor overall survival (OS).

Conclusions: Changes in the BTN3A3 expression level may play a potential key role in the carcinogenesis and development of NSCLC. Patients with low expression of BTN3A3 showed a more aggressive and invasive phenotype and a lower level of CD8+ T-cell infiltration, which may be an important factor affecting the OS of NSCLC patients.

Keywords: Non-small cell lung cancer (NSCLC); BTN3A3; tumor microenvironment (TME); multiplex immunofluorescence staining; prognosis

Submitted Jan 06, 2021. Accepted for publication Mar 11, 2021.

doi: $10.21037 / \mathrm{atm}-21-163$

View this article at: http://dx.doi.org/10.21037/atm-21-163 


\section{Introduction}

Lung cancer is a malignant tumor with the highest morbidity and mortality worldwide (1), and non-small cell lung cancer (NSCLC) accounts for $85 \%$ of cases (2). With the application of low-dose spiral computed tomography screening, the detection rate of early-stage lung cancer has improved, but many patients are still in an advanced or locally advanced stage at the time of diagnosis (3), which has a poor prognosis and survival rate. Therefore, it has always been the goal of clinicians to find specific biomarkers for earlier diagnosis and evaluate their prognostic value for lung cancer.

Butyrophilin (BTN) was first found in milk and is a type I transmembrane protein of an immunoglobulin ( $\mathrm{Ig}$ ) superfamily (4). The BTN family of genes, located at $6 \mathrm{p} 22.1$, is a group of major histocompatibility complex (MHC) related genes, which encode type I transmembrane proteins containing two extracellular Ig domains and an intracellular B30.2 domain. The three subfamilies of the human BTN gene are located in the MHC I region, and can be divided into $B T N 1, B T N 2$ and $B T N 3$, which each comprise seven genes, including $B T N 1 A 1, B T N 2 A 1, B T N 2 A 2, B T N 2 A 3$, $B T N 3 A 1, B T N 3 A 2$ and $B T N 3 A 3$ (5). The basic structure of the extracellular domain of the $B T N$ family is the same as the members of the co-stimulatory and coinhibitory molecules family (6). Therefore, BTN family molecules are considered to be B7 family-related proteins. The receptorligand interactions between members of the B7 family are widely involved in immune regulation, such as the interactions between B7.1 (CD80), B7.2 (CD86) and T-cell surface receptors CD28 and CTLA-4, which initiate T-cell activation and inhibition signals, respectively. Programmed death receptor-ligand 1 (PD-L1/CD274), PD-L2 (CD273) and its receptor PD-1 (CD279) are T-cell coinhibitory molecules (7-9). The BTN and B7 families share the same origin (10), suggesting that the BTN family may have similar immunomodulatory functions. Previous study had shown that the BTN3A1 protein plays a key role in the activation of $\gamma \delta$ T cells. By targeting the BTN3A1 receptor, the immunosuppression of $\alpha \beta \mathrm{T}$ cells can be achieved and $\gamma \delta \mathrm{T}$ cells can be activated cooperatively (11). In addition, BTN family members have many other functions and are widely involved in the occurrence of various human diseases. The rs1979 locus of the BTN3A2 gene is most significantly associated with schizophrenia. Abnormal expression of $B T N 3 A 2$ affects the balance of neuronal excitatory and inhibitory synaptic transmission activity, which increases the risk of schizophrenia (12). The expression levels of BTN1A1,
$B T N 2 A 2, B T N 3 A 3$ change significantly in inflammatory bowel disease (13). In addition, the $B T N 3 A$ subfamily has been confirmed to be expressed on the surface of a variety of tumor cells $(10,14)$. Recent studies have shown that specific single nucleotide polymorphisms in $B T N 3 A 3$ and $B T N 3 A 2$ increase the risk of ovarian cancer and gastric cancer, respectively $(15,16)$. The expression of $B T N 3 A 3$ can predict the overall survival (OS) of patients with gastric cancer who are treated with fluorouracil-based chemotherapy (17). In the tumor microenvironment (TME) of breast cancer, the LSECtin protein located on the surface of tumor-associated macrophages can promote the stemness of tumor cells by binding to BTN3A3 receptors on the surface of breast cancer stem cells (18).

BTN family members have diverse functions, which are related to the immunomodulation, initiation and progression of tumors. BTN3A3 is the membrane protein A3 of the third BTN subfamily. Compared with other BTN family members, there are few studies on $B T N 3 A 3$, and research is still in the initial stage. In particular, the expression of $B T N 3 A 3$ in NSCLC and its possible function have not been reported so far. Therefore, in-depth study of the expression of $B T N 3 A 3$ in NSCLC, and its influence on the tumor's biological behavior with expression changes and its potential role in the TME has great significance in understanding the occurrence and development mechanisms of NSCLC and the interactions between tumor and immune cells.

We present the following article in accordance with the REMARK reporting checklist (available at http://dx.doi. org/10.21037/atm-21-163).

\section{Methods}

\section{Patients}

Patients with primary NSCLC who were treated in the Department of Thoracic Surgery of Beijing Chest Hospital affiliated with Capital Medical University from January 2013 to December 2015 were included in this study. Frozen and paraffin-embedded tissue blocks of primary tumor specimens were obtained for experiments. Specific inclusion criteria were: (I) first diagnosis of NSCLC; (II) positive histopathological diagnostic results; (III) chemotherapy and radiotherapy not performed before surgery. The exclusion criteria are: (I) insufficient tumor tissue; (II) complicated with other malignant tumors; (III) incomplete clinical or follow-up data. Tumor staging was according to the 8 th edition of the American Joint 
Commission on Cancer (AJCC) staging system $(19,20)$, and the subtypes of NSCLC were classified according to the WHO guidelines (21). Patients in the study were followed up for survival and the OS was calculated according to the time period between the date of operation and the date of death or the last follow-up. This study was approved by the Ethics Committee of Beijing Chest Hospital (No. YJS-2021-010). All procedures performed in this study involving human participants were in accordance with the Declaration of Helsinki (as revised in 2013). We used frozen and paraffin-embedded tissue blocks of primary tumor specimens, which belongs to the category of exemption from informed consent.

\section{$R N A$ preparation and quantitative real-time polymerase chain reaction (rt-qPCR)}

RNA extraction reagent (RNAprep Pure Tissue Kit, RNAprep Pure, DP431) from the TianGen Company (China) was applied to extract the total RNA from NSCLC and adjacent tissues following the manufacturer's instructions. First-strand cDNA synthesis was performed using Fast Quant RT Kit With gDNase (KR106; TianGen Co., Beijing, China). rt-qPCR was performed with a Roche Light Cycler 480 system, using QuantiNova SYBR Green PCR Kit (QIAGEN). The primer for BTN3A3 were as follows: forward 5'-GCCCTCTTCAAACCTGCGG-3' and reverse 5'-AGGACACAGTAACGCCATTCA-3'. Primers for glyceraldehyde 3-phosphate dehydrogenase (GAPDH) were as follows: forward 5'-TCAAGAAGGTGGTGAAGCAGG-3' and reverse 5'-GCGTCAAAGGTGGAGGAGTG -3'. The primers were synthesized by Sangon Biotech Company (Shanghai, China). All PCR tests were repeated at least three times.

\section{Western blotting}

Cells were lysed by RIPA buffer (P0013B, Beyotime, Shanghai, China), and the protein concentration was determined by BCA Protein Quantification Kit (PC0020, Solarbio, Beijing, China). After separation by $12 \%$ SDS polyacrylamide gel, the corresponding proteins were moved to polyvinylidene difluoride (PVDF) membranes (Millipore, IPVH00010, Billerica, MA, USA). Primary antibodies specific to BTN3A3 (dilution 1:5,000, ab251692, abcam, Shanghai, China) were applied, $\beta$-actin (dilution 1:5,000, 20536-I-AP, proteintech, Chicago, USA) was used as the control.

\section{Cell culture and transfection}

Normal human bronchial epithelial cell line (16HBE), human lung adenocarcinoma cell lines (A549, H2009 and H1975) and human lung squamous cell carcinoma cell lines (H226, SK-MES-1 and H1703) were preserved in the Central Laboratory and the Department of Cellular and Molecular Biology of Beijing Chest Hospital. The cells were cultured in RPMI-1640 complete culture medium (EallBio, China) at $37^{\circ} \mathrm{C}$ in a $5 \% \mathrm{CO}_{2}$ incubator. The small interfering RNA (siRNA) transfection was performed using Lipofectamine 2000 (Invitrogen, Carlsbad, CA, USA). The knockdown effect was validated by rtqPCR and western blot. Sequences of siRNA used for transfection were as follows: BTN3A3 siRNA sense: $5^{\prime}-$ GCAACAACCAAUCAGAACCAUTT-3', BTN3A3 siRNA antisense: 5'- AUGGUUCUGAUUGGUUGUUGCTT-3'. BTN3A3 siRNA negative control (NC) sense: 5'UUCUCCGAACGUGUCACGUTT-3', BTN3A3 siRNANC anti sense: 5'- ACGUGACACGUUCGGAGAATT-3'.

\section{Scratch wound assay}

The blank control group (mock), the siRNA negative control group (NC) and the siRNA knock-down group (siRNA) cells in logarithmic growth phase were seeded in 6-well plates and cultured overnight in RPMI-1640 complete medium. After being scratched with plastic tips, the cells were cultured in serum-free medium. Wound closure was viewed at $48 \mathrm{~h}$.

\section{Transwell assay}

Transwell chambers with 6.5 -mm aperture were purchased from Corning (NY, USA). Three groups of cells were seeded in the upper chambers and $10 \%$ fetal bovine serum (FBS)-RPMI-1640 was added to the lower chambers. After culture for $24 \mathrm{~h}, 4 \%$ paraformaldehyde was used to fix for $20 \mathrm{~min}$, and gentian violet was used to stain for $20 \mathrm{~min}$. Finally, the number of migrated cells was counted under a light microscope.

\section{Colony formation test}

Three groups of cells in logarithmic growth phase were prepared for cell suspension, seeded in 6-well plates and cultured in $10 \%$ FBS-RPMI-1640 medium at a density of 1,000 cells at $37^{\circ} \mathrm{C}$ in a $5 \% \mathrm{CO}_{2}$ incubator for 2 weeks. The 
culture was terminated when the clonal cell cluster became visible by naked eye. Four percent paraformaldehyde was used to fix for $20 \mathrm{~min}$, and gentian violet was used to stain for $20 \mathrm{~min}$. Clone formation rate $=$ (number of clones formed/number of cells inoculated) $\times 100 \%$.

\section{CCK-8 proliferation assay}

The CCK-8 cell proliferation detection kit was purchased from EallBio Company (China). Three groups of cells in logarithmic growth phase were prepared for cell suspension, seeded in 96-well plates and cultured in 10\% FBS-RPMI-1640 medium at a density of 8,000 cells at $37{ }^{\circ} \mathrm{C}$ in a $5 \% \mathrm{CO}_{2}$ incubator for 24,48 , and $72 \mathrm{~h}$. Next, $10 \mu \mathrm{L}$ of CCK- 8 reagent was added $2 \mathrm{~h}$ before each detection time point and incubated without light for $2 \mathrm{~h}$. The optical density (OD) was measured at a wavelength of $450 \mathrm{~nm}$.

\section{Tissue microarray construction}

Paraffin-embedded tissue blocks of primary tumor specimens were used to construct tissue microarray (TMA) sections. Importantly, the blocks had to contain enough tumor tissue for the TMA construction. Duplicate $1.5-\mathrm{mm}$ tissue cores were randomly taken from the tumor area in the paraffin-embedded tissue blocks. TMAs containing the tissue cores were then cut into $4-\mu \mathrm{m}$ sections for multiplex immunofluorescence staining.

\section{Multiplex immunofluorescence staining and analysis}

To identify the tumor cells expressing BTN3A3 and other immune markers in the TME, multiplex immunofluorescence staining was performed using Tyramide Signal Amplification Plus Fluorescence kits (PANO 6-plex IHC Kit, Panovue, Beijing, China). Different primary antibodies were sequentially applied, followed by secondary antibody incubation and tyramide signal amplification. Between each step, the slides were washed with TBST (Tris-buffered saline + Tween 20) solution buffer three times for 3 min each time. The TMA slides were treated with microwave heat-antigen retrieval with citric acid buffer ( $\mathrm{pH}$ 6.0) after each TSA operation. Nuclei were stained with 4'-6'-diamidino-2-phenylindole after all the antibodies had been labeled. The stained slides were scanned by the Vectra system (PerkinElmer), and the multispectral images were analyzed by InForm software 2.4.8 (PerkinElmer).

\section{Statistical analysis}

Differences in means for continuous variables were compared using Student's $t$ test, and the differences in categorical variables between groups were compared using the $\chi^{2}$ test. Survival curves were plotted using the KaplanMeier method. The log-rank test was used to identify the prognostic factors of OS. Univariate and multivariate Cox regression models evaluated the hazard ratio (HRs) with $95 \%$ confidence intervals (CI) for OS. The variables with statistical significance in the univariate analysis $(\mathrm{P}<0.05)$ were included in the multivariate analysis. Spearman's rank correlation was used to analyze the correlation of quantitative data. All statistical analyses were conducted with IBM SPSS Statistics (Version 23.0), and the survival curves were drawn by GraphPad Prism v.8.0. Bilateral P value $<0.05$ was considered to be statistically significant.

\section{Results}

\section{Detection of BTN $3 A 3$ expression in clinical specimens}

A total of 75 patients were included in the study and their general clinical characteristics are shown in Table S1. Total RNA was extracted from the tumor and adjacent tissues of NSCLC patients for rt-qPCR detection. The results showed that the expression level of $B T N 3 A 3$ in tumor tissues was significantly lower than in adjacent tissues, and the difference was statistically significant $(\mathrm{P}<0.001)$. The relative expression level of $B T N 3 A 3$ in tumor and adjacent tissues is shown in Figure $1 \mathrm{~A}$.

\section{Relationship between BTN3A3 expression and patients' OS}

$B T N 3 A 3$ expression and survival time of the 75 patients was analyzed. According to the expression level of $B T N 3 A 3$ in tumor tissues, the patients were divided into two groups: high expression $(\mathrm{N}=37)$ and low expression $(\mathrm{N}=38)$. The results showed that the OS of patients with low BTN $3 A 3$ expression was significantly shorter than for those with high $B T N 3 A 3$ expression $(\mathrm{P}=0.040)$. Kaplan-Meier survival curves were plotted to represent survival in the two groups (Figure 1B).

\section{Expression of BTN3A3 in NSCLC cell lines}

Total RNA was extracted from 16HBE and 6 NSCLC cell lines for rt-qPCR detection. The results showed that the 
A

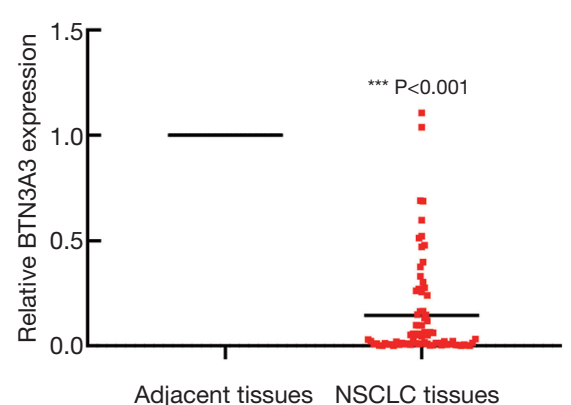

B

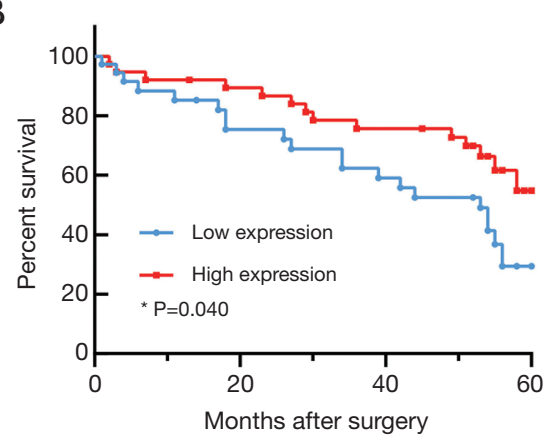

Figure 1 Association of expression level of $B T N 3 A 3$ with prognosis of NSCLC patients. (A) $B T N 3 A 3$ expression decreased significantly in NSCLC tissues compared with adjacent tissues. (B) Low expression level of BTN3A3 was associated with poor overall survival of NSCLC patients. ${ }^{*} \mathrm{P}<0.05,{ }^{* * *} \mathrm{P}<0.001$. NSCLC, non-small cell lung cancer.

A

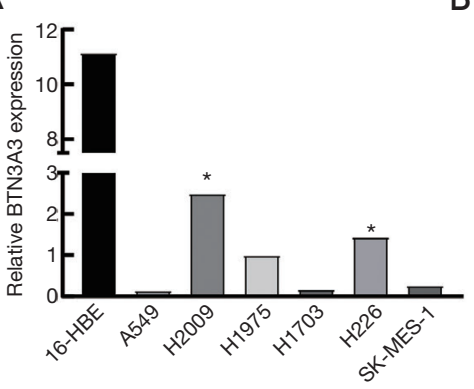

B

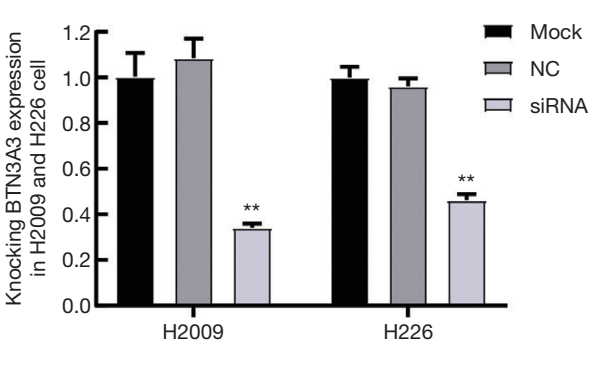

C

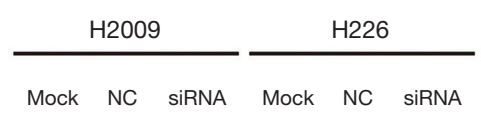

BTN3A3

$\beta$-actin

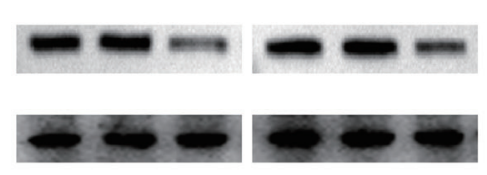

Figure 2 BTN3A3 gene expression in different NSCLC cell lines and verification of the effect of siRNA knockdown on expression. (A) Relative expression level of $B T N 3 A 3$ detected by rt-qPCR: expression level significantly decreased in human NSCLC cell lines. (B) rt-qPCR detection of the expression of BTN3A3 in mock, NC and siRNA group cells. (C) Western blot detection of the expression of $B T N 3 A 3$ protein in mock, NC and siRNA group cells. ${ }^{*} \mathrm{P}<0.05,{ }^{* *} \mathrm{P}<0.01$. NSCLC, non-small cell lung cancer; NC, negative control; siRNA, small interfering RNA; rt-qPCR, quantitative real-time PCR;

expression level of $B T N 3 A 3$ in the NSCLC cell lines was significantly lower than in the $16 \mathrm{HBE}$ cell line $(\mathrm{P}<0.05)$. In the three lung adenocarcinoma cell lines, the expression level of BTN3A3 in H2009 was significantly higher than in the H1975 and A549 cell lines $(\mathrm{P}<0.05)$, and in the three lung squamous cell carcinoma cell lines, the expression level was significantly higher in $\mathrm{H} 226$ than in the SK-MES- 1 and $\mathrm{H} 1703$ cell lines $(\mathrm{P}<0.05)$ (Figure $2 A)$.

\section{Transfection with siRNA for knock down of BTN $3 A 3$ expression in NSCLC cell lines}

The siRNA was transfected into the H2009 and H226 cell lines, and rt-qPCR was used to evaluate the efficiency of siRNA knockdown. The results showed that the expression level of $B T N 3 A 3$ in the siRNA transfection group was significantly lower than in the mock and $\mathrm{NC}$ group $(\mathrm{P}<0.05)$ (Figure $2 B$ ). The total protein of the siRNA, NC, and mock group cells was extracted for western blot assay, and the expression of BTN3A3 protein in the two siRNAtransfected cell lines was significantly decreased (Figure 2C).

\section{Effects of low expression of BTN $3 A 3$ on migration and invasion}

The siRNA was transfected into the H2009 and H226 cell lines to verify the migratory and invading abilities of NSCLC cells. The results showed that the migratory ability of the two siRNA groups was significantly higher than that of the mock and NC group $(\mathrm{P}<0.05)$ (Figure $3 A)$. And the invading ability of cells transfected with siRNA was significantly enhanced $(\mathrm{P}<0.05)$ (Figure $3 B)$. 
A

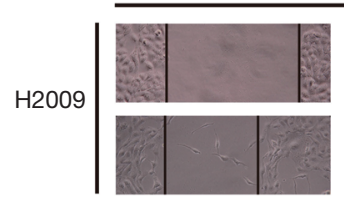

NC

siRNA
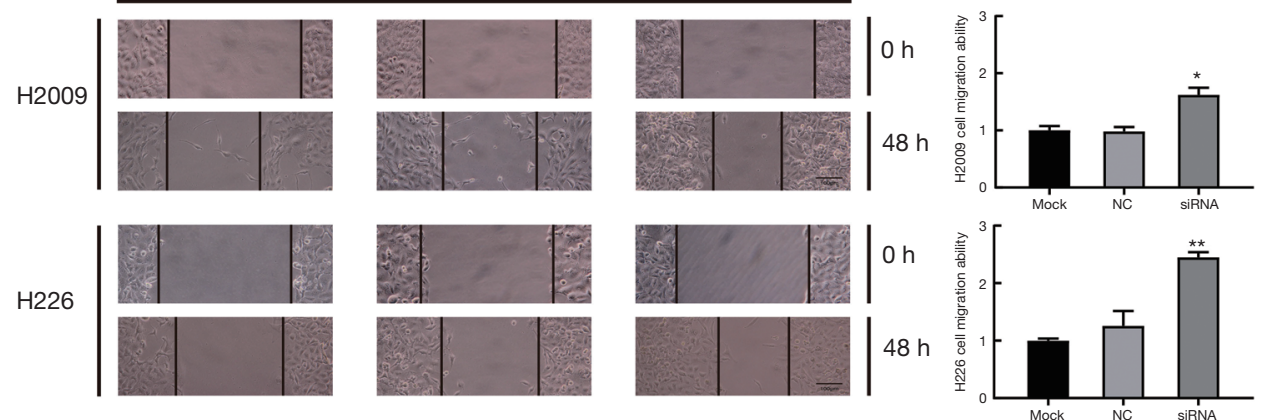

B

NC

SiRNA
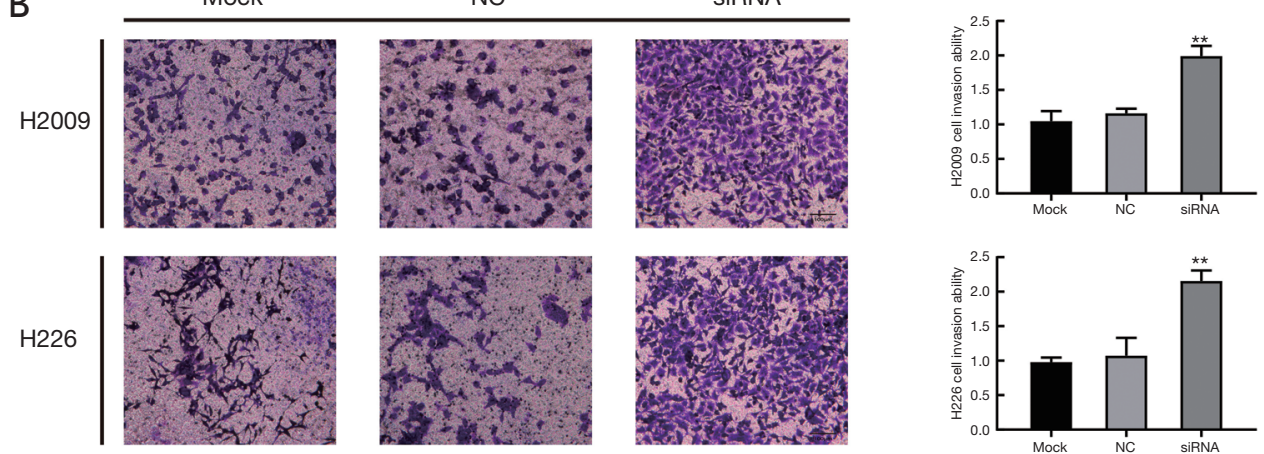

C

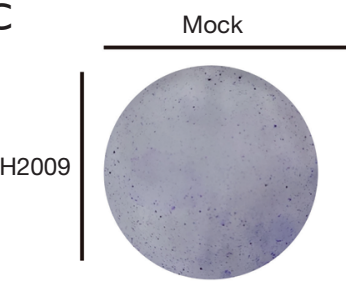

NC

siRNA
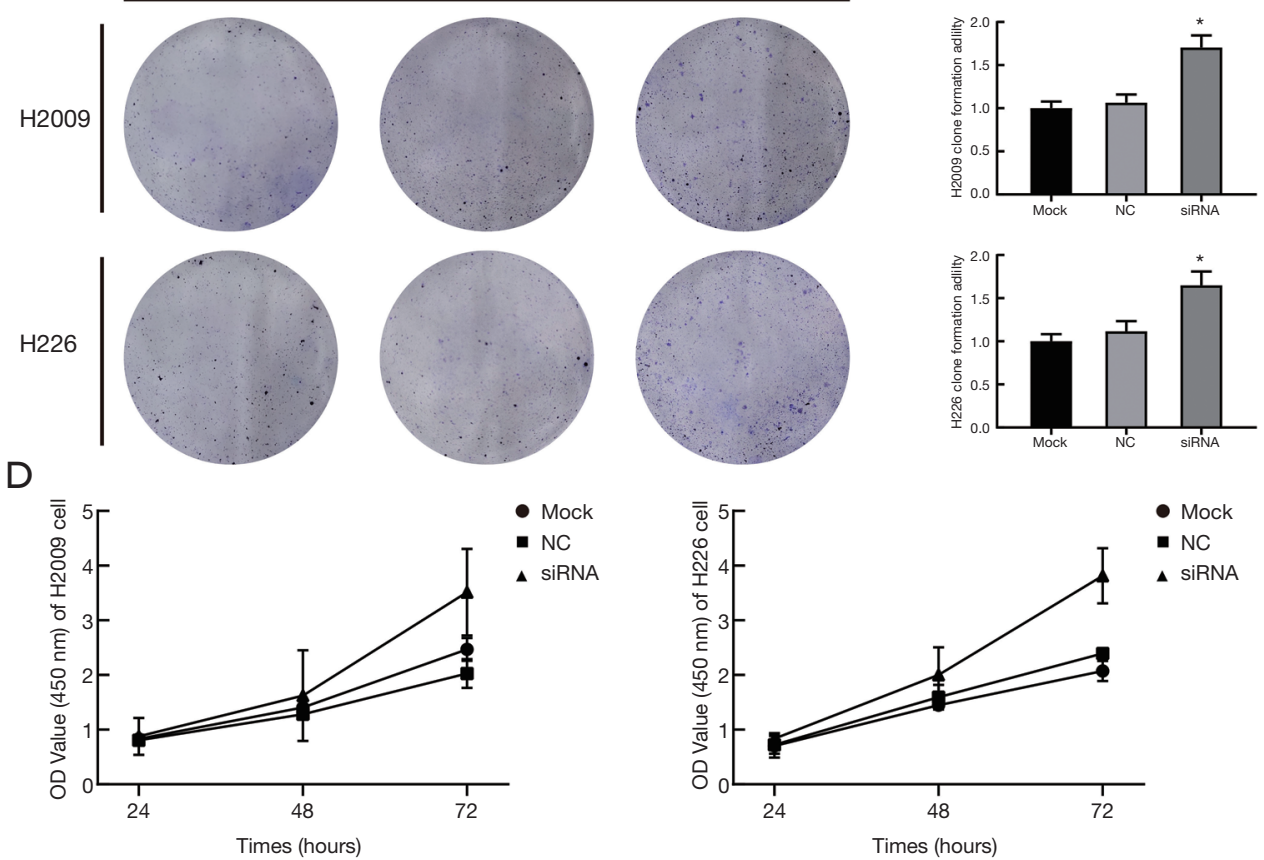

Figure 3 Effects of expression level of BTN3A3 on the proliferation, migration and invasion of NSCLC cells in the H2009 and H226 cell lines. Results for (A) migration ( $\times 200$ ), (B) invasion (gentian violet, $\times 200$ ), (C) clone formation (gentian violet, $\times 200)$ and (D) proliferation. ${ }^{*} \mathrm{P}<0.05,{ }^{* *} \mathrm{P}<0.01$. NSCLC, non-small cell lung cancer; $\mathrm{NC}$, negative control; siRNA, small interfering RNA. 


\section{Effects of low expression of BTN3A3 on cell proliferation and clone formation}

The siRNA was transfected into the H2009 and H226 cell lines to verify the proliferatory and cloning abilities of NSCLC cells. The results showed that the cloning ability of the two siRNA groups was significantly higher than that of the mock and NC group $(\mathrm{P}<0.05)$ (Figure 3C). And cell proliferation was significantly enhanced in the siRNA group $(\mathrm{P}<0.05)$ (Figure 3D).

\section{Significance of BTN3A3, CD4, CD8, CD68, and FoxP3 expression with clinicopathological characteristics}

Multiplex immunofluorescence staining was used to detect immune-related markers' expression levels in TMA slides for the NSCLC patients. 88 patients were qualified to be analyzed and finally included in the study (Figure 4). According to the density of BTN3A3 + tumor cells, the 88 patients were divided into two groups. The results showed that in clinical I+II stage, the number of patients with high expression of $B T N 3 A 3(31 / 44,70.5 \%)$ were significantly higher than those with low expression (19/44, 43.2\%), and the difference was statistically significant $(\mathrm{P}=0.010)$. Among the poorly differentiated tumors, the number of patients with low expression of $B T N 3 A 3$ (22/44, 50.0\%) were significantly higher than those with high expression $(12 / 44,27.3 \%)$, and the difference was statistically significant $(\mathrm{P}=0.029)$. The general clinical characteristics of these patients and detailed results are shown in Table S2. We also quantified the density of BTN3A3 + tumor cells and infiltrating immune cells, and analyzed their relationship with the clinicopathological characteristics of the patients. The results showed that the density of $\mathrm{BTN} 3 \mathrm{A3}^{+}$tumor cells was significantly higher in patients with earlier clinical stage $(\mathrm{P}=0.033)$ (Figure $5 A)$ and with higher degree of tumor differentiation $(\mathrm{P}=0.048)$ (Figure 5B); The density of $\mathrm{CD} 8^{+} \mathrm{T}$ cells in the tumor area was significantly higher in patients with earlier clinical tumor $\mathrm{T}$ stage $(\mathrm{P}=0.035)$; The density of FoxP $3^{+} \mathrm{T}$ cells in the tumor area was significantly higher in the late clinical stage $(\mathrm{P}=0.030)$, whereas the density of $\mathrm{CD}^{+} \mathrm{T}$ cells in the stroma was significantly higher in patients with earlier clinical tumor T stage $(\mathrm{P}=0.030)$. Detailed results are shown in Table 1 .

\section{Correlation between density of $\mathrm{BTN} 3 \mathrm{~A}^{+}$tumor cells, $\mathrm{CD} 8^{+}$macrophages, and $\mathrm{CD}^{+}, \mathrm{CD}^{+}$and $\mathrm{FoxP}^{+} \mathrm{T}$ cells}

$\mathrm{BTN} 3 \mathrm{~A}^{+}$tumor cell density positively correlated with
$\mathrm{CD}^{+} \mathrm{T}$-cell density in the tumor area $(\mathrm{r}=0.265, \mathrm{P}=0.012)$ (Figure $6 \mathrm{~A}$ ). $\mathrm{CD}^{+} 8^{+}$macrophage density in the tumor area positively correlated with $\mathrm{CD} 4^{+} \mathrm{T}$-cell density in the tumor area $(\mathrm{r}=0.322, \mathrm{P}=0.002)$ and $\mathrm{CD} 68^{+}$macrophage density in the stroma $(r=0.447, \mathrm{P}<0.001)$. CD4 ${ }^{+} \mathrm{T}$-cell density in the tumor area positively correlated with $\mathrm{CD} 8^{+} \mathrm{T}$-cell density in the tumor area $(\mathrm{r}=0.322, \mathrm{P}=0.002)$, and with $\mathrm{CD}^{+} \mathrm{T}$-cell density ( $\mathrm{r}=0.573, \mathrm{P}<0.001), \mathrm{CD}^{+} \mathrm{T}$-cell density $(\mathrm{r}=0.281$, $\mathrm{P}=0.008)$, and FoxP3 ${ }^{+}$T-cell density $(\mathrm{r}=0.238, \mathrm{P}=0.026)$ in the stroma. $\mathrm{CD}^{+} \mathrm{T}$-cell density in the tumor area positively correlated with $\mathrm{CD}^{+}{ }^{+} \mathrm{T}$-cell density $(\mathrm{r}=0.224, \mathrm{P}=0.036)$ and the $\mathrm{CD}^{+} \mathrm{T}$-cell density $(\mathrm{r}=0.558, \mathrm{P}<0.001)$ in the stroma. And the FoxP $3^{+} \mathrm{T}$-cell density in the tumor area positively correlated with the FoxP3 ${ }^{+}$T-cell density in the stroma $(\mathrm{r}=0.352, \mathrm{P}=0.001)$. Detailed results are shown in Table 2 .

\section{Effects of clinicopathological features and TME on OS}

The 88 patients were followed up for 60 months, during which 67 patients died, giving a mortality rate of $76.14 \%$. The relationships between prognosis and clinicopathological features, TME immune markers $\left(\mathrm{BTN} 3 \mathrm{~A} 3^{+}\right.$tumor cell density, tumor and stromal immune cell densities), radiotherapy and chemotherapy were analyzed. Univariate analysis showed that OS was significantly prolonged in patients aged $\leq 60$ years $(P=0.034)$, with earlier tumor $T$ stage $(\mathrm{P}=0.005)$, without lymph node metastasis $(\mathrm{P}<0.001)$, with earlier clinical stage $(\mathrm{P}<0.001)$, without postoperative radiotherapy $(\mathrm{P}=0.049)$, with higher $\mathrm{BTN} \mathrm{A3}^{+}$tumor cell density $(\mathrm{P}=0.041)$ (Figure $6 B)$, and with higher $\mathrm{CD} 8^{+}$ T-cell density $(\mathrm{P}<0.01)$ (Figure $6 C)$ in the tumor area. The difference was statistically significant. Detailed results are shown in Table S3.

\section{Discussion}

In this study, we used clinical tumor specimens to detect the expression of $B T N 3 A 3$, and the results showed that its expression in tumor tissues was significantly lower than in adjacent tissues, which preliminarily indicates that a change in $B T N 3 A 3$ expression may play a key role in the carcinogenesis and progression of NSCLC. The OS of patients with low expression was significantly shortened. We used siRNA to transfect NSCLC cell lines to knock down $B T N 3 A 3$ expression. The results showed that low expression of $B T N 3 A 3$ promoted the proliferation, migration and invasion of NSCLC cells. We further investigated the associations between tumor BTN3A3 expression, as well 

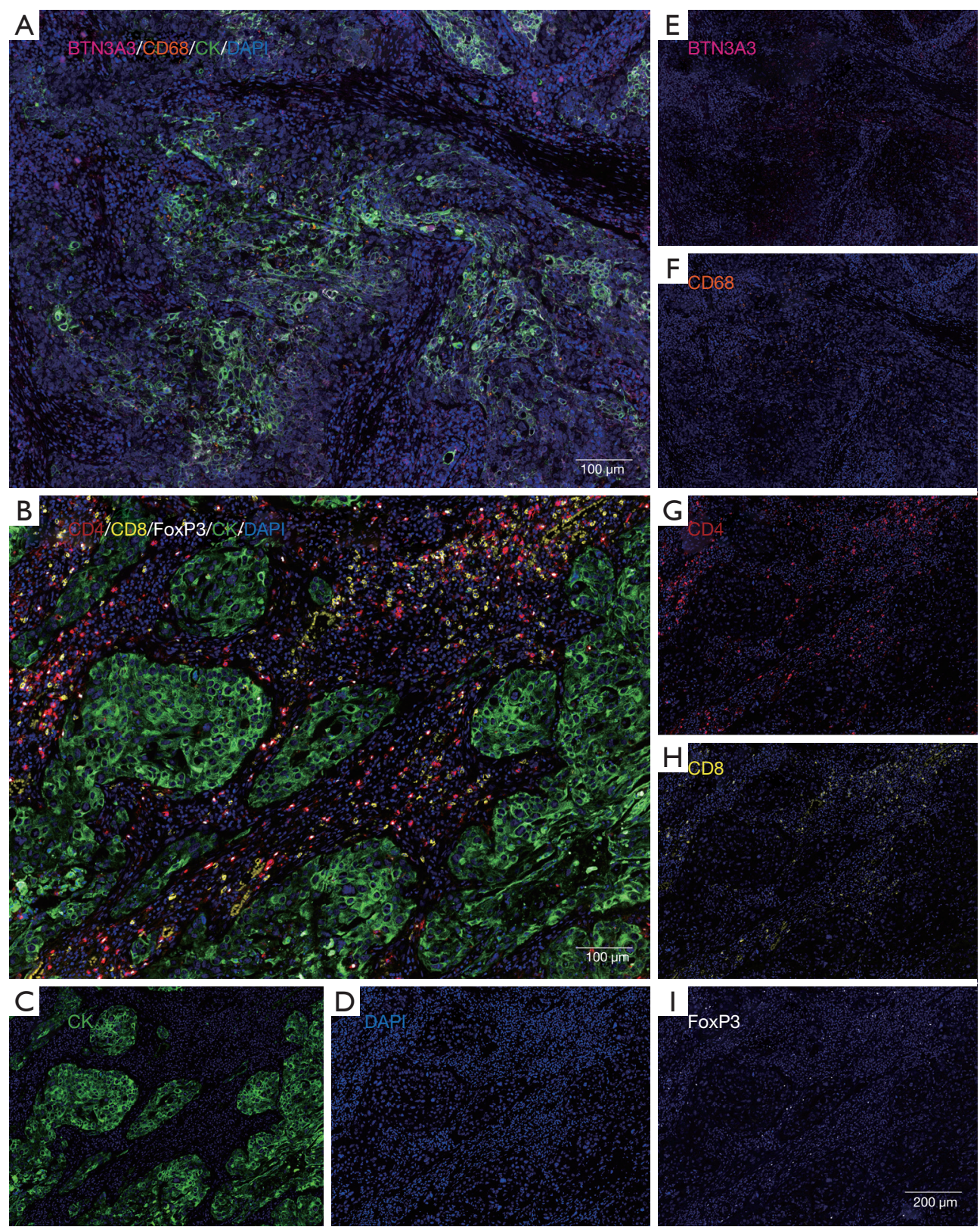

Figure 4 Expression of specific marker positive cells detected by multiplex immunofluorescence staining. The tumor and stromal areas were divided by CK. (A) Merged image of BTN3A3, CD68, CK and DAPI. (B) Merged image of CD4, CD8, FoxP3, CK and DAPI. (C) CK expression (green), (D) DAPI (blue), (E) BTN3A3 expression (magenta), (F) CD68 expression (orange), (G) CD4 expression (red), (H) CD8 expression (yellow) and (I) FoxP3 expression (white). FoxP3: forkhead box transcription factor P3. CK: cytokeratin. DAPI: 4'-6'-diamidino2-phenylindole.

as that of CD4, CD8, CD68 and FoxP3, in the TME, and the clinicopathological characteristics and OS of 88 NSCLC patients using the multiplex immunofluorescence staining technique. We found that the expression of BTN3A3 was relatively high in the early clinical stage and well-differentiated tumors, suggesting that patients with low expression may have a more invasive phenotype. In addition, the density of $\mathrm{BTN} \mathrm{A}^{+}{ }^{+}$tumor cells positively correlated with the density of $\mathrm{CD}^{+} \mathrm{T}$ cells in the tumor area, suggesting that the expression of $B T N 3 A 3$ is closely 
A

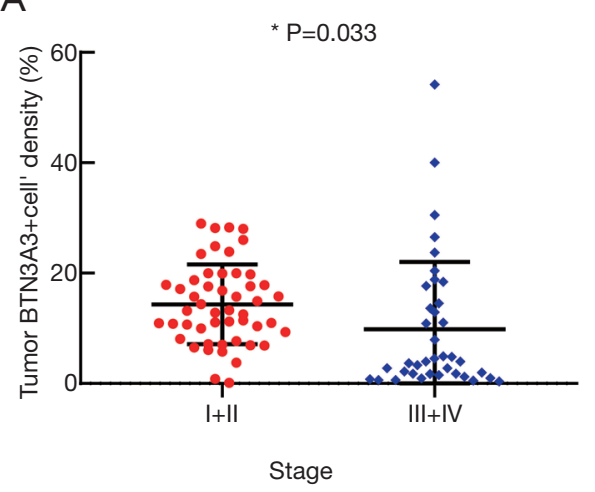

B

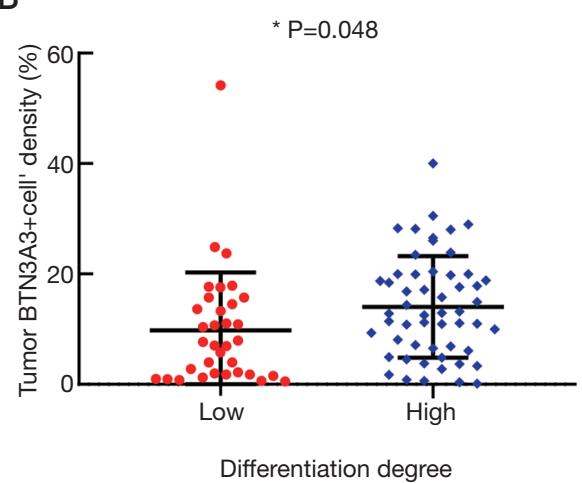

Figure 5 Relationship between BTN3A3+ tumor cell density and clinicopathological features. (A) Density of BTN3A3+ tumor cells in patients with clinical I+II stage is significantly higher than that in clinical III+IV stage. (B) Density of BTN3A3+ tumor cells in patients with low tumor differentiation is significantly lower than that in patients with high tumor differentiation. ${ }^{*} \mathrm{P}<0.05$.

related to immune cell infiltration and immune response. In addition, the expression level of BTN3A3 protein was associated with the patients' prognosis, and low expression showed a poor OS. At present, there are few studies of the BTN3A subfamily, especially on BTN3A3 expression in NSCLC. This is the first time $B T N 3 A 3$ has been studied at the level of gene and protein expressions, and we confirmed that low expression of $B T N 3 A 3$ promotes the proliferation, migration and invasion of NSCLC cells. We quantitatively explored the relationship between $\mathrm{BTN} 3 \mathrm{~A}^{+}$tumor cells and immune cell infiltration in the TME, and our results indicated that $B T N 3 A 3$ may play a potential role in the evaluation of long-term prognosis of NSCLC patients. Our study provides a new clinical basis for improving our understanding of the mechanism of occurrence and development of NSCLC and finding specific prognostic indicators and therapeutic targets.

Tumorigenesis is usually accompanied by aberrant alterations in the expression levels of genes involved in cell proliferation, such that the tumor cell growth is uncontrolled, and ultimately leads to tumor metastasis. To date, there are few studies of changes in the expression of BTN family genes, and how they are involved in the process of tumorigenesis. In an ovarian cancer study, Peedicayil et al. found that a single nucleotide polymorphism of $B T N 3 A 3$ negatively correlated with the incidence of ovarian cancer (16). In a gastric cancer study, Pan et al. established an analytical model and confirmed that $B T N 3 A 3$ can predict the OS of postoperative patients receiving fluorouracil chemotherapy (17). In a recent study, Liu $e t a l$. reported that LSECtin on the surface of tumorassociated macrophages directly interacts with the BTN3A3 on the surface of breast cancer cells, which promoted the stemness of breast cancer cells in the TME (18). Blocking the LSECtin-BTN3A3 signal axis may be a potential treatment for breast cancer. These results suggested that $B T N 3 A 3$ may also play a key role in regulating the stemness of tumor cells in NSCLC, or mediating the escape of tumor stem cells through interaction with tumor-associated macrophages. On the other hand, during carcinogenesis, tumor formation and metastasis, the interaction between tumor cells and stromal cells (including immune cells, endothelial cells, fibroblasts, etc.) persists in the TME. Both antitumor immunity and tumor metastasis require the dynamic participation of a variety of immune cells. Therefore, the inclusion of more immune cells as the evaluation index of NSCLC would have important clinical implications for better prediction of tumor initiation, progression, metastasis and recurrence.

Tumor infiltrating lymphocytes (TILs) are a heterogeneous lymphocyte population that mainly exists in the TME, and are closely related to the antitumor immune response. TILs have significant effect on facilitating tumor immunity escape $(22,23) . \mathrm{CD}^{+} \mathrm{T}$ cells are considered to be effector cells in the immune system that directly kill tumor cells. Studies have shown that infiltration of a higher number of $\mathrm{CD}^{+} \mathrm{T}$ cells is related to a better clinical outcome of various cancers (including hepatocarcinoma, esophageal cancer, colon cancer, and ovarian cancer, etc.) (24-27). In our study, we found that the density of $\mathrm{BTN}_{3} \mathrm{~A}^{+}$tumor cells positively correlated with the density of $\mathrm{CD}^{+} \mathrm{T}$ cells in the tumor area, which may be one of the reasons for the better survival of patients with high expression of $B T N 3 A 3$. However, whether the expression of $B T N 3 A 3$ affects the function of $\mathrm{CD} 8^{+} \mathrm{T}$ cells, and how to the regulatory 


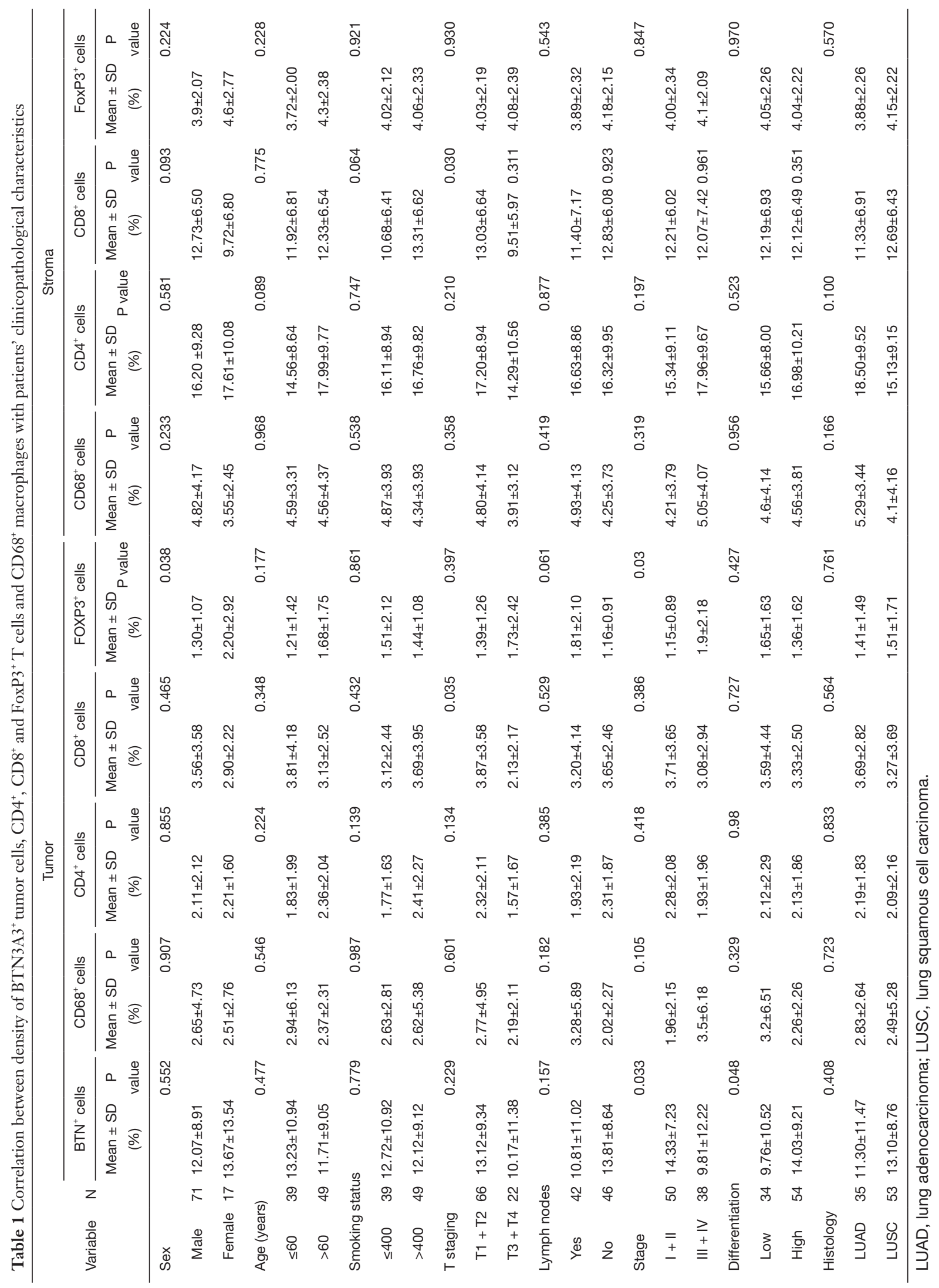


A

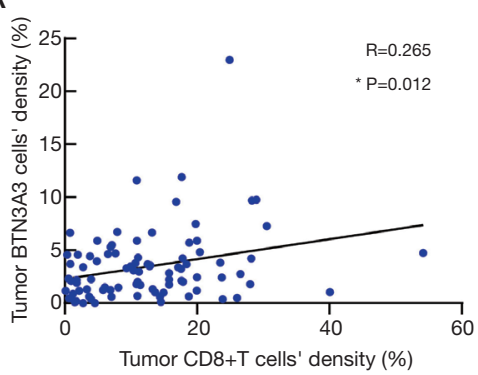

B

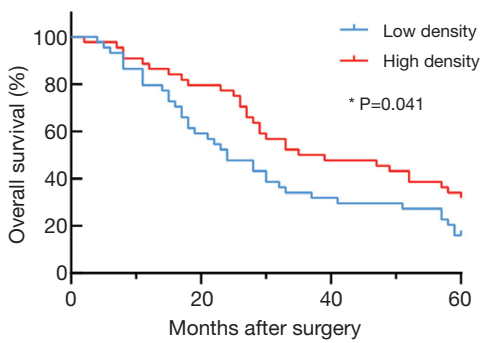

C

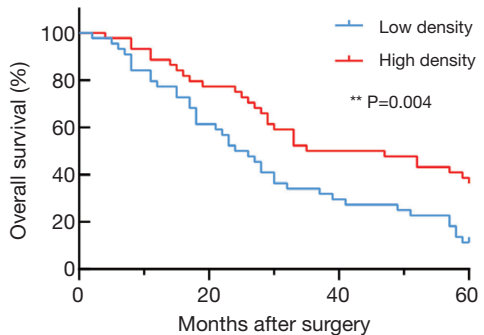

Figure 6 Relationship between $\mathrm{BTN}^{\mathrm{A} 3^{+}}$tumor cells and immune cell infiltration, and effects of different immunophenotypic cells on OS. (A) $\mathrm{BTN}_{3} \mathrm{~A}^{+}$tumor cell density positively correlates with $\mathrm{CD} 8^{+} \mathrm{T}$-cell density in the tumor area. (B) Low BTN3A3 ${ }^{+}$tumor cell density associated with poor OS of NSCLC patients. (C) High CD8 ${ }^{+}$T-cell density in tumor area associated with better OS of the NSCLC patients. ${ }^{*} \mathrm{P}<0.05,{ }^{* *} \mathrm{P}<0.01$. OS, overall survival; NSCLC, non-small cell lung cancer.

role plays out between them, need to be further studied. In addition to inhibiting $\mathrm{CD}^{+} \mathrm{T}$ cells, another mechanism for tumor cells' immune escape is to recruit $\mathrm{T}$ regulatory cell (Tregs) into the TME $(28,29)$. Tregs are a specific T-cell subset. Natural Tregs (nTregs) have mature functions, which depend on the expression of forkhead box transcription factor P3 (FoxP3) (30,31). nTregs functionally inhibit the activation or proliferation of a variety of immune cells, then suppresses the immune response, and finally promote tumor growth and metastasis. Therefore, many studies have confirmed that the existence of Tregs is negatively associated with tumor prognosis $(32,33)$. In this study, we did not find a significant correlation between density of $\mathrm{BTN}_{3} \mathrm{~A}^{+}$tumor cells and the density of $\mathrm{FoxP}^{+} \mathrm{T}$ cells in the tumor or stroma. On the one hand, it is considered that the expression of $B T N 3 A 3$ in tumor cells is not an influencing factor for $\mathrm{FoxP}^{+} \mathrm{T}$-cell infiltration. However, patients with low $B T N 3 A 3$ expression show a late tumor stage and lower degree of differentiation, indicating that low expression of $B T N 3 A 3$ and $\mathrm{FoxP}^{+} \mathrm{T}$-cell infiltration may be differently involved in the regulation of tumor immunity escape. In addition, we did not find a relationship between the expression of $B T N 3 A 3$ in tumor cells and $\mathrm{CD}^{+}{ }^{+} \mathrm{T}$-cell infiltration. Considering that $\mathrm{CD} 4^{+} \mathrm{T}$ cells comprise multiple heterogeneous cell subsets (34,35), different subsets may play various roles in the TME, so it is also unknown whether $B T N 3 A 3$ is involved in the regulation of the different subsets of $\mathrm{CD}^{+} \mathrm{T}$ cells. Finally, the relationship between the expression of BTN3A3 and $\mathrm{CD}_{68}^{+}$macrophage infiltration has not been found; however, the latest study has preliminarily proved that the target of LESCtin protein expressed on macrophages is the BTN3A3 protein expressed on the surface of breast cancer stem cells, which could help us understand the function of BTN3A3 in the future, explore the mechanism of tumor metastasis, and provide an important reference for monitoring and evaluating the prognosis of NSCLC.

In conclusion, downregulated expression of $B T N 3 A 3$ in NSCLC is related to invasive clinicopathological features and poor OS. Low expression of $B T N 3 A 3$ promotes the proliferation, migration and invasion of NSCLC cells. In the TME, the expression of $B T N 3 A 3$ in tumor tissue positively correlated with infiltration of $\mathrm{CD} 8^{+} \mathrm{T}$ cells, which may be an important factor affecting long-term survival. This study reveals a new suppressor gene involved in the carcinogenesis of NSCLC, which is expected to become a potential prognostic marker and therapeutic target for NSCLC patients. 


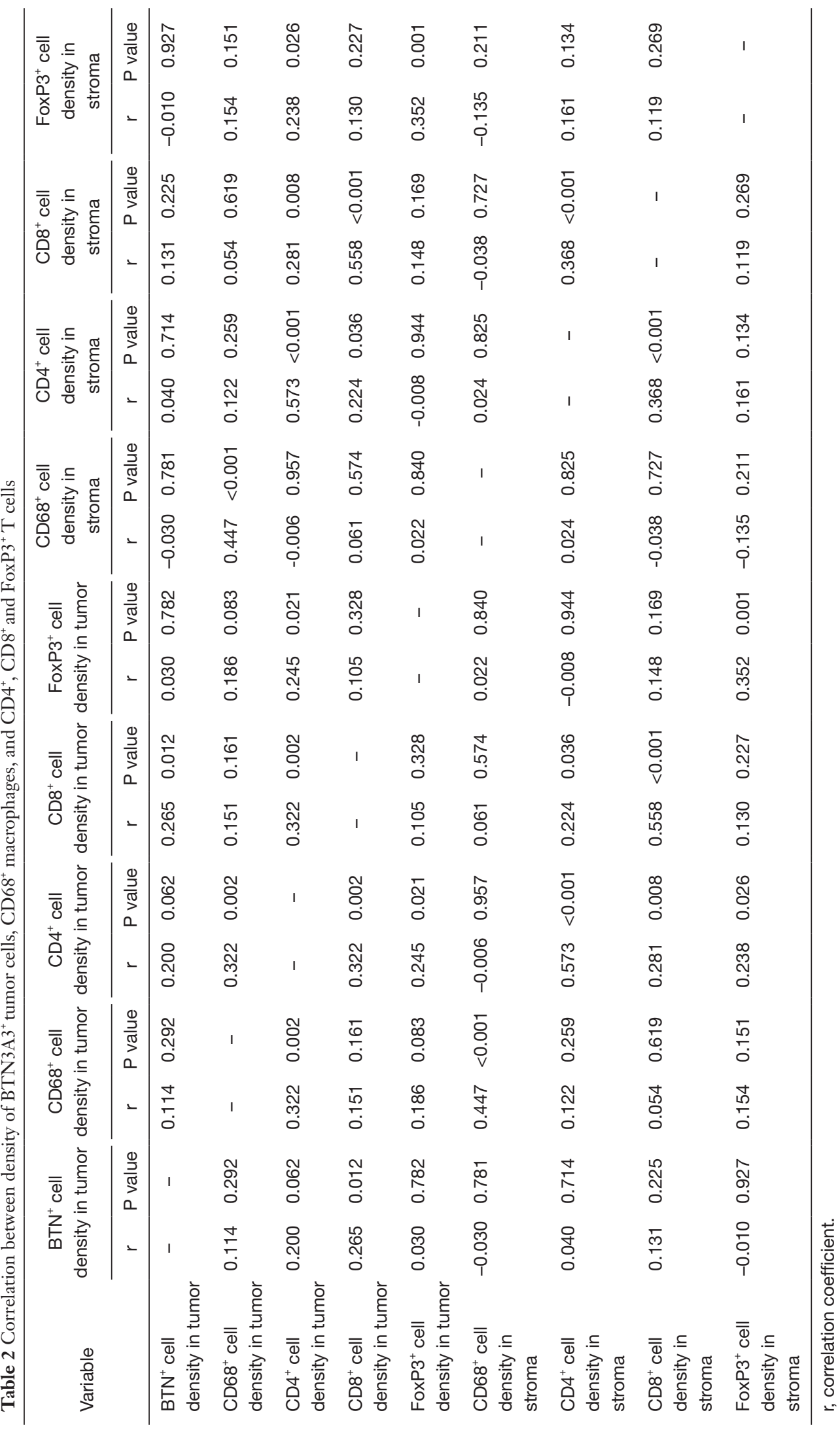




\section{Acknowledgments}

We thank colleagues and members of the Pathology Department of Beijing Chest Hospital for their assistance with experiments.

Funding: None.

\section{Footnote}

Reporting Checklist: The authors have completed the REMARK reporting checklist. Available at http://dx.doi. org/10.21037/atm-21-163

Data Sharing Statement: Available at http://dx.doi. org/10.21037/atm-21-163

Conflicts of Interest: All authors have completed the ICMJE uniform disclosure form (available at http://dx.doi. org/10.21037/atm-21-163). The authors have no conflicts of interest to declare.

Ethical Statement: The authors are accountable for all aspects of the work in ensuring that questions related to the accuracy or integrity of any part of the work are appropriately investigated and resolved. This study was approved by the Ethics Committee of Beijing Chest Hospital (No. YJS-2021-010). All procedures performed in this study involving human participants were in accordance with the Declaration of Helsinki (as revised in 2013). Informed consent was taken from all the patients.

Open Access Statement: This is an Open Access article distributed in accordance with the Creative Commons Attribution-NonCommercial-NoDerivs 4.0 International License (CC BY-NC-ND 4.0), which permits the noncommercial replication and distribution of the article with the strict proviso that no changes or edits are made and the original work is properly cited (including links to both the formal publication through the relevant DOI and the license). See: https://creativecommons.org/licenses/by-nc-nd/4.0/.

\section{References}

1. Siegel RL, KD Miller, A Jemal. Cancer statistics, 2020. CA Cancer J Clin 2020;70:7-30.

2. Herbst RS, Morgensztern D, Boshoff C. The biology and management of non-small cell lung cancer. Nature 2018;553:446-54.
3. Mauguen A, Pignon JP, Burdett S, et al. Surrogate endpoints for overall survival in chemotherapy and radiotherapy trials in operable and locally advanced lung cancer: a re-analysis of meta-analyses of individual patients' data. Lancet Oncol 2013;14:619-26.

4. Moyzis RK, Buckingham JM, Cram LS, et al. A highly conserved repetitive DNA sequence, (TTAGGG)n, present at the telomeres of human chromosomes. Proc Natl Acad Sci USA 1988;85:6622-6.

5. Arnett HA, Viney JL. Immune modulation by butyrophilins. Nat Rev Immunol 2014;14:559-69.

6. Afrache H, Gouret P, Ainouche S, et al. The butyrophilin (BTN) gene family: from milk fat to the regulation of the immune response. Immunogenetics 2012;64:781-94.

7. Schildberg FA, Klein SR and Freeman GJ, et al. Coinhibitory Pathways in the B7-CD28 Ligand-Receptor Family. Immunity 2016;44:955-72.

8. Ni L, Dong C. New B7 Family Checkpoints in Human Cancers. Mol Cancer Ther 2017;16:1203-11.

9. Ni L, Dong C. New checkpoints in cancer immunotherapy. Immunol Rev 2017;276:52-65.

10. Compte E, Pontarotti P, Collette Y, et al. Frontline: Characterization of $\mathrm{BT} 3$ molecules belonging to the B7 family expressed on immune cells. Eur J Immunol 2004:34:2089-99.

11. Payne KK, Mine JA, Biswas S, et al. BTN3A1 governs antitumor responses by coordinating alphabeta and gammadelta T cells. Science 2020;369:942-9.

12. Wu Y, Bi R, Zeng C, et al. Identification of the primatespecific gene BTN3A2 as an additional schizophrenia risk gene in the MHC loci. Ebiomedicine 2019;44:530-41.

13. Lebrero-Fernandez C, Wenzel UA, Akeus $P$, et al. Altered expression of Butyrophilin (BTN) and BTN-like (BTNL) genes in intestinal inflammation and colon cancer. Immun Inflamm Dis 2016;4:191-200.

14. Cubillos-Ruiz JR, Martinez D, Scarlett UK, et al. CD277 is a negative co-stimulatory molecule universally expressed by ovarian cancer microenvironmental cells. Oncotarget 2010;1:329-38.

15. Zhu M, Yan C, Ren C, et al. Exome Array Analysis Identifies Variants in SPOCD1 and BTN3A2 That Affect Risk for Gastric Cancer. Gastroenterology 2017;152:2011-21.

16. Peedicayil A, Vierkant RA, Hartmann LC, et al. Risk of ovarian cancer and inherited variants in relapse-associated genes. Plos One 2010;5:e8884.

17. Pan J, Dai Q, Xiang Z, et al. Three Biomarkers Predict Gastric Cancer Patients' Susceptibility To Fluorouracilbased Chemotherapy. J Cancer 2019;10:2953-60. 
18. Liu D, Lu Q, Wang X, et al. LSECtin on tumorassociated macrophages enhances breast cancer stemness via interaction with its receptor BTN3A3. Cell Res 2019;29:365-78.

19. Amin MB, Greene FL, Edge SB, et al. The Eighth Edition AJCC Cancer Staging Manual: Continuing to build a bridge from a population-based to a more "personalized" approach to cancer staging. CA Cancer J Clin 2017;67:93-9.

20. Kutob L, Schneider F. Lung Cancer Staging. Surg Pathol Clin 2020;13:57-71.

21. Travis WD, Brambilla E, Burke AP, et al. Introduction to The 2015 World Health Organization Classification of Tumors of the Lung, Pleura, Thymus, and Heart. J Thorac Oncol 2015;10:1240-2.

22. Peled M, Onn A, Herbst RS. Tumor-Infiltrating Lymphocytes-Location for Prognostic Evaluation. Clin Cancer Res 2019;25:1449-51.

23. Besser MJ, Shapira-Frommer R, Schachter J. TumorInfiltrating Lymphocytes: Clinical Experience. Cancer J 2015;21:465-9.

24. Xu X, Tan Y, Qian Y, et al. Clinicopathologic and prognostic significance of tumor-infiltrating CD8+ T cells in patients with hepatocellular carcinoma: A meta-analysis. Medicine (Baltimore) 2019;98:e13923.

25. Schumacher K, Haensch W, Roefzaad C, et al. Prognostic significance of activated CD8(+) T cell infiltrations within esophageal carcinomas. Cancer Res 2001;61:3932-6.

26. Funada Y, Noguchi T, Kikuchi R, et al. Prognostic significance of CD8+ T cell and macrophage peritumoral infiltration in colorectal cancer. Oncol. Rep 2003;10:309-13.

27. Kroeger DR, Milne K, Nelson BH. Tumor-Infiltrating

Cite this article as: Cheng X, Ma T, Yi L, Su C, Wang X, Wen T, Wang B, Wang Y, Zhang H, Liu Z. Low expression of BTN3A3 indicates poor prognosis and promotes cell proliferation, migration and invasion in non-small cell lung cancer. Ann Transl Med 2021;9(6):478. doi: 10.21037/atm-21-163
Plasma Cells Are Associated with Tertiary Lymphoid Structures, Cytolytic T-Cell Responses, and Superior Prognosis in Ovarian Cancer. Clin Cancer Res 2016;22:3005-15.

28. Wolf D, Sopper S, Pircher A, et al. Treg(s) in Cancer: Friends or Foe? J Cell Physiol 2015;230:2598-605.

29. Whiteside TL. What are regulatory T cells (Treg) regulating in cancer and why? Semin Cancer Biol 2012;22:327-34.

30. Sakaguchi S, Setoguchi R, Yagi H, et al. Naturally arising Foxp3-expressing CD25+CD4+ regulatory T cells in selftolerance and autoimmune disease. Curr Top Microbiol Immunol 2006;305:51-66.

31. Ono M, Yaguchi H, Ohkura N, et al. Foxp3 controls regulatory T-cell function by interacting with AML1/ Runx1. Nature 2007;446:685-9.

32. Santoiemma PP, Powell DJ. Tumor infiltrating lymphocytes in ovarian cancer. Cancer Biol Ther 2015;16:807-20.

33. Takeuchi Y, Nishikawa H. Roles of regulatory T cells in cancer immunity. Int Immunol 2016;28:401-9.

34. Oja AE, Piet B, van der Zwan D, et al. Functional Heterogeneity of CD4(+) Tumor-Infiltrating Lymphocytes With a Resident Memory Phenotype in NSCLC. Front Immunol 2018;9:2654.

35. Chalmin F, Humblin E, Ghiringhelli F, et al. Transcriptional Programs Underlying Cd4 T Cell Differentiation and Functions. Int Rev Cell Mol Biol 2018;341:1-61.

(English Language Editor: K. Brown) 
Supplementary

Table S1 Characteristics of patients with BTN3A3 gene expression detected by quantitative fluorescence PCR

\begin{tabular}{|c|c|c|c|c|}
\hline Variable & Low expression $(\mathrm{N}=38)$ & High expression ( $\mathrm{N}=37$ ) & $\chi^{2}$ & $P$ value \\
\hline Age & & & 0.11 & 0.740 \\
\hline$\leq 60$ years old & 30 & 28 & & \\
\hline$>60$ years old & 8 & 9 & & \\
\hline Gender & & & 1.07 & 0.300 \\
\hline Male & 15 & 19 & & \\
\hline Female & 23 & 18 & & \\
\hline Tumor size & & & 6.36 & 0.042 \\
\hline$\leq 30 \mathrm{~mm}$ & 11 & 20 & & \\
\hline $30-50 \mathrm{~mm}$ & 18 & 9 & & \\
\hline$>50 \mathrm{~mm}$ & 9 & 8 & & \\
\hline Lymph nodes & & & 1.38 & 0.240 \\
\hline Positive & 14 & 9 & & \\
\hline Negative & 24 & 28 & & \\
\hline Histology & & & 4.80 & 0.030 \\
\hline LUSC & 26 & 16 & & \\
\hline LUAD & 12 & 21 & & \\
\hline Stage & & & 6.08 & 0.048 \\
\hline I & 10 & 20 & & \\
\hline ॥ & 12 & 8 & & \\
\hline III & 16 & 9 & & \\
\hline Chemotherapy & & & 0.01 & 0.930 \\
\hline Yes & 15 & 15 & & \\
\hline No & 23 & 22 & & \\
\hline Radiotherapy & & & 0.19 & 0.660 \\
\hline Yes & 3 & 4 & & \\
\hline No & 35 & 33 & & \\
\hline
\end{tabular}

LUSC, lung squamous cell carcinoma; LUAD, lung adenocarcinoma. 
Table S2 Characteristics of patients with BTN3A3 ${ }^{+}$tumor cells detected by multiplex immunofluorescence staining

\begin{tabular}{|c|c|c|c|c|c|c|}
\hline Variables & \multicolumn{2}{|c|}{ Low cell density } & \multicolumn{2}{|c|}{ High cell density } & $\chi^{2}$ & $P$ value \\
\hline Gender & & & & & 0.66 & 0.418 \\
\hline Male & 34 & 77.3 & 37 & 84.1 & & \\
\hline Female & 10 & 22.7 & 7 & 15.9 & & \\
\hline$\leq 60$ years old & 18 & 40.9 & 21 & 47.7 & & \\
\hline$>60$ years old & 26 & 59.1 & 23 & 52.3 & & \\
\hline Smoking status & & & & & 0.05 & 0.830 \\
\hline$\leq 400$ & 20 & 45.5 & 19 & 43.2 & & \\
\hline $\mathrm{T} 1+\mathrm{T} 2$ & 30 & 68.2 & 36 & 81.8 & & \\
\hline $\mathrm{T} 3+\mathrm{T} 4$ & 14 & 31.8 & 8 & 18.2 & & \\
\hline Lymph nodes & & & & & 1.64 & 0.200 \\
\hline Yes & 24 & 54.5 & 18 & 40.9 & & \\
\hline No & 20 & 45.5 & 26 & 59.1 & & \\
\hline Stage & & & & & 6.67 & 0.010 \\
\hline $\mathrm{I}+\mathrm{II}$ & 19 & 43.2 & 31 & 70.5 & & \\
\hline III+ IV & 25 & 56.8 & 13 & 29.5 & & \\
\hline LUSC & 24 & 54.5 & 29 & 56.9 & & \\
\hline
\end{tabular}

LUAD, lung adenocarcinoma; LUSC, lung squamous cell carcinoma. 
Table S3 Univariate and multivariate analyses of overall survival in patients with different BTN3A3+ tumor cell density

\begin{tabular}{|c|c|c|c|c|c|}
\hline Variables & $\begin{array}{c}\text { Total numbers of patients/ } \\
\text { death }(\mathrm{N} / \mathrm{n})\end{array}$ & \multicolumn{2}{|l|}{ Univariate analysis } & \multicolumn{2}{|c|}{ Multivariate analysis } \\
\hline Male & $71 / 57$ & $28.0(24.330,31.670)$ & & & \\
\hline$\leq 60$ years old & $39 / 26$ & $37.0(13.751,60.249)$ & & $0.50(0.29-0.86)$ & \\
\hline$>60$ years old & $49 / 41$ & $27.0(21.285,32.715)$ & & Reference & \\
\hline Smoking status & & & 0.162 & & \\
\hline T staging & & & 0.005 & & 0.842 \\
\hline $\mathrm{T} 1+\mathrm{T} 2$ & $66 / 47$ & $33.0(15.095,50.905)$ & & $0.93(0.47-1.85)$ & \\
\hline $\mathrm{T} 3+\mathrm{T} 4$ & $22 / 20$ & $18.0(8.807,27.193)$ & & Reference & \\
\hline Lymph nodes & & & $<0.001$ & & 0.091 \\
\hline Positive & $42 / 40$ & $26.0(22.035,29.965)$ & & $1.75(0.91-3.36)$ & \\
\hline Negative & $46 / 27$ & $52.0(30.952,73.048)$ & & Reference & \\
\hline Stage & & & $<0.001$ & & 0.159 \\
\hline High & $54 / 39$ & $29.0(21.799,36.201)$ & & & \\
\hline Histology & & & 0.073 & & \\
\hline LUAD & $35 / 23$ & $33.0(20.292,45.708)$ & & & \\
\hline LUSC & $53 / 44$ & $27.0(21.905,32.095)$ & & & \\
\hline Chemotherapy & & & 0.468 & & \\
\hline Yes & $51 / 41$ & $29.0(26.376,31.624)$ & & & \\
\hline No & $37 / 26$ & $33.0(7.178,58.822)$ & & & \\
\hline Radiotherapy & & & 0.049 & & 0.264 \\
\hline Yes & $17 / 16$ & $28.0(15.899,40.101)$ & & $1.45(0.76-2.79)$ & \\
\hline No & $71 / 51$ & $33.0(23.115,42.885)$ & & Reference & \\
\hline
\end{tabular}

Table S3 (continued) 
Table S3 (continued)

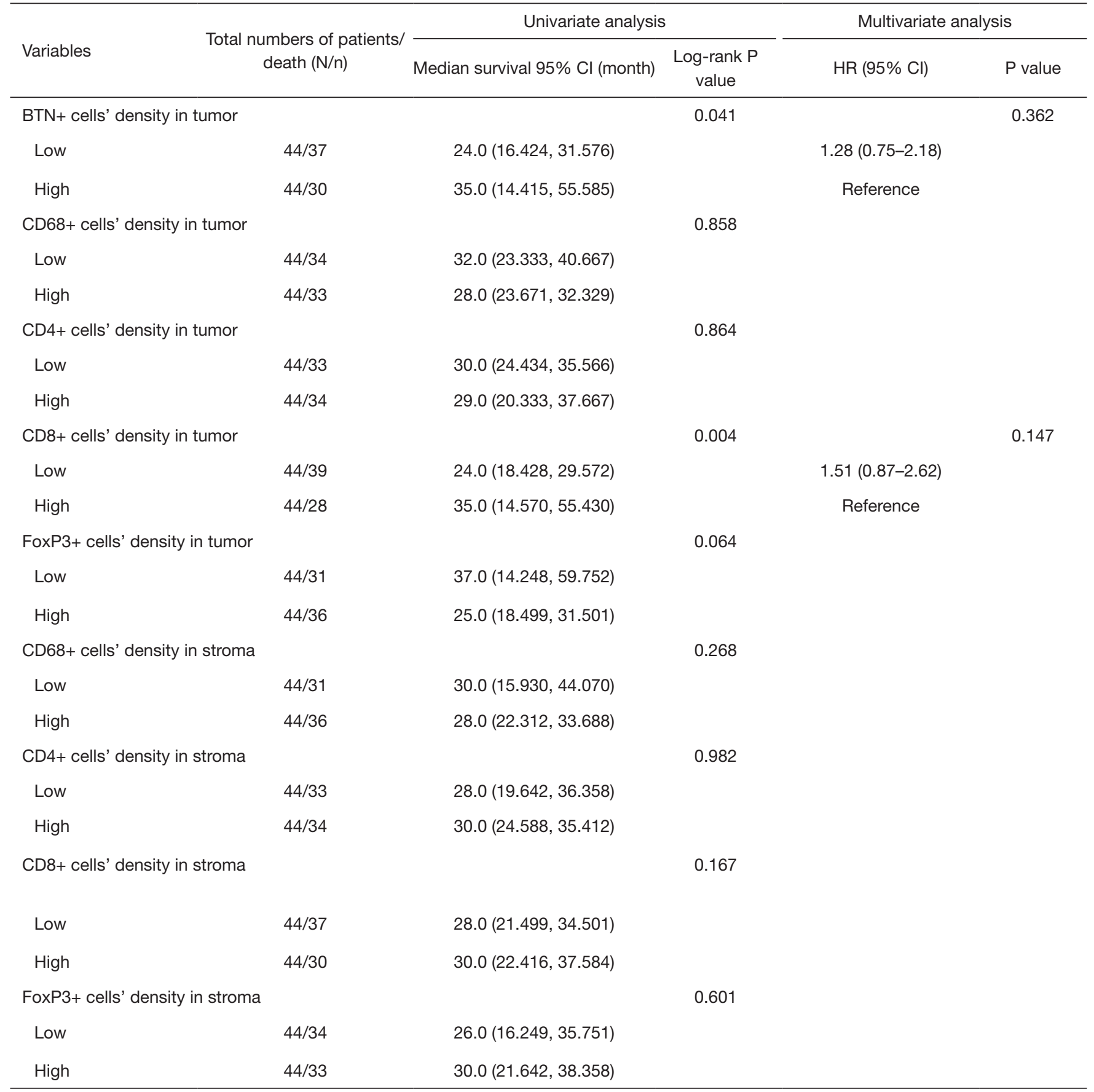

LUAD, lung adenocarcinoma; LUSC, lung squamous cell carcinoma. 